\title{
Robinson Crusoe's Earthenware Pot
}

\author{
Lydia H. Liu
}

Virginia Woolf once made a remarkable observation about Daniel Defoe's novel Robinson Crusoe. Call it intuition or uncanny lucidity. Under her eyes, an insignificant detail, which has largely escaped the attention of Defoe's critics, emerges out of obscurity and becomes luminous all of a sudden. The illumination radiates from a plain earthenware pot that practically dominates the physical environment of Crusoe's world. Although Defoe's reader will remember that this pot is but one of many survival tools that Crusoe has invented during his solitary existence on the island, Woolf insists on seeing more. In her reading, the object acquires an enigmatic symbolism:

Thus Defoe, by reiterating that nothing but a plain earthenware pot stands in the foreground, persuades us to see remote islands and the solitudes of the human soul. By believing fixedly in the solidity of the pot and its earthiness, he has subdued every other element to

This essay has gone through several stages of revisions since I first presented it at the Center for Chinese Studies at the University of California, Berkeley; the Humanities Institute of Stanford University; the Science Studies Program of the University of California, San Diego; the University of Washington; and the Massachusetts Institute of Technology. I wish to thank the following individuals for their generous comments on the earlier versions of this paper: Elizabeth Helsinger, Michael Fischer, Roger Hart, Paul Rabinow, Judith Klein, Mary Campbell, Marta Hanson, Chandra Mukerji, Neil De Marchi, Leo Ou-fan Lee, and Tuo Li. I am grateful to Noah Heringman, Larissa Heinrich, Chaela Pastore, and Shaden Tageldin for their valuable input at different stages of this research. 
his design; he has roped the whole universe into harmony. And is there any reason, we ask as we shut the book, why the perspective that a plain earthenware pot exacts should not satisfy us as completely, once we grasp it, as man himself in all his sublimity standing against a background of broken mountains and tumbling oceans with stars flaming in the sky?

Taking Crusoe's pot as a primary figure of representation in the novel, Woolf directs our attention to a productive metonymy between man and the thing he makes and to the possible limits of such metonymic figuring. In her reading, Defoe's (or rather Crusoe's) fixation on the solidity and earthiness of the pot takes on an aura of fetishism that evokes both the historicity of the metonymy and its aesthetic implications in the eighteenth century. The pot can thus be read as a fetish, though not a primitive's fetish but a modern man's, because it carries the symbolic burden of human intentionality that threatens to subdue the natural elements to his design. The image of Defoe or Crusoe roping the whole universe into harmony is just as disturbing as it is violent, which is, perhaps, what prompted Woolf to raise the rhetorical question toward the end of the quoted passage. But her question is not entirely rhetorical because it also casts a slight shade of ambiguity upon Crusoe's dubious identity as the inventor and owner of the earthenware pot. Among other things, I attribute this ambiguity to the uncertain identity of the pot itself caused by the accidental happening of its making in the original context of Defoe's narrative. That which produces the accident of Crusoe's pottery, I argue, can be grasped both in terms of the circumstance of the novel's first publication in 1719 and in terms of the anachronism of Crusoe's mode of production, popularized by the classical political economists and criticized by Marx in Capital. ${ }^{2}$

1. Virginia Woolf, "Robinson Crusoe," in The Second Common Reader (New York, 1960), pp. $48-49$.

2. The classical political economists from the eighteenth century onward often used Robinson Crusoe as their favorite model of illustration. The solitary individual on a desert island served as a convenient starting point for building their systems. Concerning the "primitive" character of Crusoe's production, Marx offers a sarcastic comment: "Necessity itself compels him to apportion his time accurately between different kinds of work. Whether one kind occupies a greater space in his general activity than another, depends

Lydia H. Liu teaches in the departments of comparative literature and East Asian languages at the University of California, Berkeley. She is the author of Translingual Practice: Literature, National Culture, and Translated Modernity - China, 1900-1937 (1995) and the editor of Tokens of Exchange: The Problem of Translation in Global Circulations (1999). 


\section{From Science Fiction to Realism}

Woolf's reading of Robinson Crusoe is intriguing for a number of reasons. I am particularly drawn to her suggestion of fetishism, and I wonder if we could further elaborate the figure of fetishized metonymy between Crusoe and his pottery not with a view to resolving Woolf's own ambiguity but with a view to following the traces of that metonymy to a larger, possibly global, network of metonymic exchange within which Defoe's earthenware episode was embedded and to which the novel Robinson Crusoe has made singular contributions. I emphasize the global network of metonymic exchange in this essay because we are dealing with some of the consequences of early modern global circulation that had predated and preconditioned European colonialism.

In a recently published study of the early modern economy, ReOrient: Global Economy in the Asian Age, Andre Gunder Frank again reminds us how, from the early fifteenth century through the beginning of the nineteenth century, "Europeans sought to muscle in on the richest trade in the world," referring to the intra-Asian trade, and how colonization finally enabled Europeans to achieve that goal.

Europeans derived more profits from their participation in the intraAsian "country trade" than they did from their Asian imports into Europe, even though many of the latter in turn generated further profits for them as re-exports to Africa and the Americas. So the Europeans were able to profit from the much more productive and wealthy Asian economies by participating in the intra-Asian trade;

on the difficulties ... to be overcome in attaining the useful effect aimed at. This our friend Robinson soon learns by experience, and having rescued a watch, ledger, and pen and ink from the wreck, commences, like a true-born Briton, to keep a set of books" (Karl Marx, Capital: A Critique of Political Economy, trans. Samuel Moore and Edward Aveling, 3 vols. [New York, 1967], 1:76-77). Marx criticizes David Ricardo for using Crusoe in this manner: "He makes the primitive hunter and the primitive fisher straightway, as owners of commodities, exchange fish and game in the proportion in which labour-time is incorporated in these exchange-values. On this occasion he commits the anachronism of making these men apply to the calculation, so far as their implements have to be taken into account, the annuity tables in current use on the London Exchange in the year 1817. 'The parallelograms of Mr. Owen' appear to be the only form of society, besides the bourgeois form, with which he was acquainted" (ibid., 1:81n). Insisting on the social nature of economic production, Marx rejected Adam Smith's and Ricardo's fiction of homo economicus, pointing out that

the individual and isolated hunter or fisher who forms the starting point with Smith and Ricardo, belongs to the insipid illusions of the eighteenth century. They are Robinsonades which do not by any means represent, as students of the history of civilization imagine, a reaction against over-refinement and a return to a misunderstood natural life. They are no more based on such a naturalism than is Rousseau's "contrat social," which makes naturally independent individuals come in contact and have mutual intercourse by contract. They are the fiction and only the aesthetic fiction of the small and great Robinsonades. [Marx, A Contribution to the Critique of Political Economy, trans. N. I. Stone (Chicago, 1913), pp. 265-66] 
and that in turn they were able to do ultimately only thanks to their American silver. ${ }^{3}$

Among the familiar Asian commodities sought after by the Europeans in early modern times were silk, tea, calicos, and porcelain (chinaware). Chinese porcelain, also known as true (white) porcelain, was traded around the globe and eagerly copied by potters elsewhere. By the late seventeenth and early eighteenth centuries, porcelain had become the single most fashionable luxury in the homes of the European aristocracy. Indeed, it was porcelain, not earthenware, that widely circulated in the global network of metonymic exchange in Defoe's time. ${ }^{4}$ This is something we need to keep in mind when reexamining the earthenware episode in his novel.

The artifact Crusoe makes in Robinson Crusoe is called earthenware, not porcelain, and there seems no reason why we should ask the novel to do otherwise. However, Defoe's novel was written at the height of the European craze for true porcelain, and in the same period the author published several journalistic pieces arguing against imported chinaware and its negative impact on the British economy and morals. ${ }^{5}$ Viewed against this background, the earthenware episode in Robinson Crusoe appears doubly interesting. Defoe's journalistic writing shows that he was not uninterested in the symbolic and technological difference between earthenware and porcelain. In fact, during King William's reign, Defoe himself attempted the manufacture of bricks and pantiles (S-shaped earthenware tiles developed in Holland) in response to the rising demand for construction materials for the rebuilding and expansion of London. In partnership with others, he became proprietor of a brickyard in the 1690s. According to Paula R. Backscheider, the Essex factory was Defoe's major business enterprise, from which he came to clear about six hundred

3. Andre Gunder Frank, ReOrient: Global Economy in the Asian Age (Berkeley, 1998), p. 282.

4. See J. A. Lloyd Hyde and Ricardo R. Espirito Santo Silva, Chinese Porcelain for the European Market (1956; Lisbon, 1994); John Goldsmith Phillips, China Trade Porcelain: An Account of Its Historical Background, Manufacture, and Decoration and a Study of the Helena Woolworth McCann Collection (Cambridge, Mass., 1956); and David Howard and John Ayers, China for the West: Chinese Porcelain and Other Decorative Arts for Export Illustrated from the Mottahedeh Collection, 2 vols. (London, 1978).

5. Defoe was reacting to the birth of consumerism in the early eighteenth century, which also saw the rise of European chinoiserie. Werner Sombart and Fernand Braudel diagnosed chinoiserie as the conspicuous consumption of luxury in the early stages of capitalism. See Werner Sombart, Luxury and Capitalism, trans. W. R. Dittmar (1913; Ann Arbor, Mich., 1967), and Fernand Braudel, The Structures of Everyday Life, trans. Siân Reynolds (Berkeley, 1992). Bruce P. Lenman's recent study shows that the English population on both sides of the Atlantic experienced "its first great wave of consumerism, in which imported Asiatic products and manufactures played an important role" (Bruce P. Lenman, "The English and Dutch East India Companies and the Birth of Consumerism in the Augustan World," Eighteenth-Century Life 14 [Feb. 1990]: 62). 
pounds a year and which he believed to be a firmer foundation for his family's future economic security than his other projects. ${ }^{6}$ But King William's reign was also a time when export Chinese porcelain prevailed on the global market and culminated in the rise of European chinoiserie, which would dictate the taste of the aristocracy in the next few decades. Deeply critical of this new trend, Defoe took King William and Queen Mary to task for having introduced four customs of excess that were imitated by the people and became worshipped by the whole kingdom: gardening, painting, East Indian calicos, and Chinese porcelain. Defoe argued that the royal taste had descended "into the humours of the common people so much, as to make them greivous to our trade, and ruining to our manufactures and the poor; so that the Parliament were oblig'd to make two Acts at several times to restrain, and at last prohibit the use of them." Of export porcelain, Defoe wrote:

The queen brought in the custom or humour, as I may call it, of furnishing houses with china-ware, which increased to a strange degree afterwards, piling their china upon the tops of cabinets, scrutores, and every chymney-piece, to the tops of the ceilings, and even setting up shelves for their china-ware, where they wanted such places, till it became a grievance in the expence of it, and even injurious to their families and estates. ${ }^{7}$

Defoe's antipathy toward King William and Queen Mary aside, the curious configuration of ceramic objects in his life and writing is well worth pondering. As a business entrepreneur, he manufactured pantiles and earthenware, as does Crusoe in his novel, but at the same time Defoe was an outspoken critic of imported chinaware and went so far as to ridicule porcelain in the second volume of Robinson Crusoe. The motif of rivalry between earthenware and true porcelain in his writing no doubt expressed Defoe's protectionist stance against the penetration of the national market by foreign luxury products. Yet the economic rivalry was never a purely economic phenomenon but was readily translatable into metonymic associations at the discursive level, where earthenware would almost always evoke porcelain, and vice versa, in the eighteenth century. The presence of the earthenware pot in Robinson Crusoe, therefore, evokes porcelain by metonymic association and calls up the existence of the latter by virtue of its absence.

What I am trying to suggest here is that the rivalries among economies and civilizations in the eighteenth century seemed to have undergone an extraordinary process of metamorphosis in Defoe's novel for it to become a tale of (white) man's solitary survival in nature. In that sense,

6. See Paula R. Backscheider, Daniel Defoe: His Life (Baltimore, 1989), pp. 64-65.

7. Daniel Defoe, A Tour through the Whole Island of Great Britain (1724-1726) (London, 1962), 1:165-66, 166. 
Crusoe's experiment with earthenware is symptomatic of what I call the poetics of colonial disavowal. The analysis that follows is an attempt to show that this poetics of colonial disavowal informs Defoe's storytelling in profound ways, both stylistically and contextually. To understand how it functions in the text, one cannot simply substitute one allegorical reading (of the survival tale) for another but would do well to interrogate the very absence of porcelain in the Crusoe episode and to try to explain how that absence conditions what the earthenware pot is doing, metonymically, in the novel. For porcelain is a significant absence in volume 1 of Robinson Crusoe. Like a ghost, the foreign object hovers over the borders of Defoe's writing and wrestles with the authorial hand that tries to exclude it from signification.

Even as the solidity and singularity of Crusoe's earthenware pot as recognized by Woolf seem ready to dissolve and metamorphose into something else, there is yet another level of complexity to be considered in this study. In keeping with the desire to control and regulate the value of luxury commodities on the inventory list of imported goods and to manufacture imitation products for competition on a global market, early eighteenth-century Europe witnessed a growing scientific interest in how one might distinguish among true porcelain, soft-paste porcelain, and other types of ceramics, and how to fix those distinctions categorically. Alchemists and/or scientists put years of painstaking research into discovering and determining the differential scientific (interior) value of white porcelain as opposed to the more familiar European soft-paste (pâte tendre) ware and earthenware. My research shows that the meaning of true porcelain at this time was shot through with Europeans' curiosity about the basic components of chinaware, then reported to be the Chinese clay kaolin and the porcelain stone petuntse. The quest for the local variants of these materials, therefore, introduced an interesting metaphysical disjuncture between true porcelain on the one hand and earthenware and soft-paste porcelain such as faïence and delftware on the other. In other words, chinaware was singled out to represent essential difference from ordinary ceramics and soft-paste porcelain from a scientific point of view because that difference and the distinction it conferred on the object mattered a great deal in terms of quality and value to contemporary merchants, scientists, collectors, and manufacturers. ${ }^{8}$

That said, what new insight can we glean from Crusoe's earthenware episode? Could it lead to a new interpretation of Robinson Crusoe? In a

8. Indeed, chinaware became a trope that could figure other kinds of difference as well. For example, John Gay, Defoe's contemporary, wrote a satirical poem entitled "To a Lady on her Passion for Old China" in 1725. In it, womanhood and porcelain evoke each other metonymically and synecdochically, whereas manhood is equated to earthenware, rough on the surface but sturdy on the inside. Gay's poem spells out an aesthetics of materiality categorically grounded in the metaphysics of appearance and reality, surface and depth, femininity and masculinity, and so on. 
fine chapter, "Robinson Crusoe and Friday," in his study Colonial Encounters, Peter Hulme takes issue with the two main strands of criticism of Defoe's novel since Ian Watt's influential 1957 book The Rise of the Novel, namely, Watt's own thesis of economic individualism and "'formal realism" on the one hand and the "'spiritual' reading" of the novel as "a Puritan fable" on the other. ${ }^{9}$ With regard to Robinson Crusoe's place in literary history as the first true work of realism, Hulme identifies the following grounds as central to Watt's argument. First, Robinson Crusoe is the preeminent novel of the "individualism" that characterizes modern realist fiction; second, it fulfills more generally the criteria of Watt's formal realism; and, finally, the novel demonstrates, in Crusoe's wanderings, "the dynamic tendency of capitalism itself, whose aim is never merely to maintain the status quo, but to transform it incessantly." ${ }^{10}$ Hulme argues that these grounds fall apart when the episodic or seemingly formless plot of Defoe's novel fails to live up to Watt's own criteria of formal realism and intrinsic coherence-that touchstone of bourgeois aesthetics.

To help solve this difficulty and recuperate the formal sophistication and narrative coherence of Robinson Crusoe, some critics began to approach it as a Puritan spiritual tale by analogy with the Puritan journal. ${ }^{11}$ According to this line of argument, there is an underlying spiritual pattern in Robinson Crusoe that enables the narrator to make sense of his daily experience by negotiating providential meanings in an immediate recording of the crowded sensations of the lived moment. Rather than formal realism, the spiritual pattern is what gives Defoe's narrative its true significance. However, this reading strategy and its pursuit of narrative coherence run up against another set of interpretive problems. In Hulme's words, "the 'spiritual' reading of Robinson Crusoe attempts-unsuccessfully - to remedy the scandal of the secular text whose interpretation is not guided by any authorial voice, but which has been published as the character's own story, 'Written by Himself', an assertion, as Watt rightly saw, of the primacy of individual experience as defiant in its ownfictional-way as Descartes' cogito ergo sum" (CE, p. 179). In a nutshell, the disagreement between the realist and spiritual readings of Robinson Crusoe has led to two very different Defoes by Hulme's account: against Watt's 'modern' Defoe-Defoe/Richardson/Fielding-is set a seventeenthcentury Defoe-Milton/Bunyan/Defoe.

9. Peter Hulme, Colonial Encounters: Europe and the Native Caribbean 1492-1797 (1986; London, 1992), p. 176; hereafter abbreviated $C E$.

10. Ian Watt, The Rise of the Novel: Studies in Defoe, Richardson, and Fielding (Berkeley, 1957), p. 65; quoted in $C E$, p. 176.

11. By Hulme's account, the two main studies usually invoked for this pervasive spiritual motif are G. A. Starr, Defoe and Spiritual Autobiography (Princeton, N.J., 1965), and J. Paul Hunter, The Reluctant Pilgrim: Defoe's Emblematic Method and Quest for Form in Robinson Crusoe (Baltimore, 1966). 
Seeking a possible alternative to the above, Hulme proposes to read Robinson Crusoe as a Caribbean book or colonial narrative. He argues that the new subjectivity that emerges in the course of Defoe's novel "is simultaneously an individual and a national consciousness, both forged in the smithy of a Caribbean that is-as of course the Caribbean still is to England-both parabolic and historical at the same time. Concomitantly, the social relationships involved are simultaneously personal and international" (CE, p. 216). The same view was forcibly expressed by James Joyce, whose words are quoted by Hulme as follows: "The true symbol of the British conquest is in Robinson Crusoe.... The whole Anglo-Saxon spirit is in Crusoe; the manly independence and the unconscious cruelty; the persistence; the slow yet efficient intelligence; the sexual apathy; the practical, well-balanced, religiousness; the calculating taciturnity." ${ }^{12}$ By emphasizing the social relationship of the personal and international, Hulme seems to be shifting the ground of Defoe's realism from the earlier critics' formalist argument and spiritual reading to a study of colonial subjectivity. His analysis of the colonial exchange between Crusoe and Friday, for example, makes a good case toward illustrating that "the imperial production of Robinson Crusoe as a boys' adventure in the nineteenth century inevitably foregrounds the colonial alibi-the man alone, on a desert island, constructing a simple and moral economy which becomes the basis of a commonwealth presided over by a benevolent sovereign" (CE, p. 222).

While Hulme's insight is immensely useful for our rethinking of Defoe's novel and English literature in general, the New Historicist twist on realism in his argument still begs the question of how colonialism grounded and governed its own realism. Indeed, the imperial production of Robinson Crusoe as a boys' adventure does produce a colonial alibi, but the realism of that alibi needs further interrogation. In Émile, for instance, Rousseau provides what has long been regarded as the standard pedagogical reading of Defoe's novel as a children's tale. In book 3, Rousseau writes:

Robinson Crusoé dans son île, seul, dépourvu de l'assistance de ses semblables et des instrumens de tous les arts, pourvoyant cependant à sa subsistance, à sa conservation, et se procurant même une sorte de bien-être, voilà un objet intéressant pour tout âge, et qu'on a mille moyens de rendre agréable aux enfans. Voilà comment nous réalisons l'île déserte qui me servoit d'abord de comparaison.

[Robinson Crusoe on his island, deprived of the help of his fellowmen, without the means of carrying on the various arts, yet finding

12. James Joyce, "Daniel Defoe," trans. and ed. Joseph Prescott, Buffalo Studies 1 (1964): 24-25; quoted in CE, p. 216. 
food, preserving his life, and procuring a certain amount of comfort; this is the thing to interest people of all ages, and it can be made attractive to children in all sorts of ways. We shall thus make a reality of that desert island which formerly served as an illustration. $]^{13}$

What does Rousseau mean by "voilà comment nous réalisons l'île déserte qui me servoit d'abord de comparaison"? Perhaps this is where one might hope to gain some insight into the status of the real both in and outside Defoe's novel. The matter is further complicated by Rousseau's observation that Émile's mimicking of Robinson Crusoe is like building a "vrai château en Espagne de cet heureux âge, où l'on ne connoît d'autre bonheur que le nécessaire et la liberté" [genuine castle in the air of this happy age, when the child knows no other happiness but food and freedom] (EO, p. $156 ; E$, p. 148; emphasis added). The interesting slippage between "nous réalisons" and "vrai château en Espagne" in Rousseau's language could be explained away by the assumption that a child's unfettered imagination cannot distinguish between these things in the first place. But Emile is a philosophical treatise written for educated adults whose claims to reason were predicated precisely on their ability to distinguish between the realm of the real and castles in the air and who would say of Émile, as Rousseau himself puts it in his preface, that "on croira moins lire un traité d'éducation que les rêverie d'un visionnaire sur l'éducation" [this is not so much a treatise on education as the visions of a dreamer with regard to education] ( $E O$, p. 2; $E$, p. 2; emphasis added). Rousseau's tacit admission to having dreamed up an elaborate castle in the air suggests an interesting figurative exchange between Émile and Robinson Crusoe. I argue that this economy of exchange took place in the imaginary realm of protoscience fiction, where Rousseau's technology of pedagogy found itself responding creatively to elements of science fiction in Defoe's novel.

Which is to say that Émile foregrounds the science fiction of Defoe's novel by casting itself as a science fiction of sorts, one about the technology of pedagogy, although Rousseau was neither the first nor the last to do so. Jules Verne, the celebrated inventor of science fiction, inherited this economy of figurative exchange from Defoe and Rousseau in the nineteenth century and openly acknowledged Robinson Crusoe as a major source of inspiration for all his works. "My story," says Captain Grant of The Children of Captain Grant, "is that of all Robinsons thrown up on an island." ${ }^{14}$ I should also mention that recent cinematic reincarnations of Defoe's hero, such as Robinson Crusoe on Mars and Enemy Mine, further

13. J. J. Rousseau, Émile, ou de l'éducation, in Oeuvres complètes de J. J. Rousseau, 13 vols. (Paris, 1905-12), 2:156, emphasis added, hereafter abbreviated EO; trans. Barbara Foxley, under the title Émile (1911; London, 1963), p. 147, emphasis added, hereafter abbreviated $E$.

14. Quoted in Peter Costello, Jules Verne: Inventor of Science Fiction (New York, 1978), p. 94. Peter Redfield drew my attention to the Verne legacy, and I thank him here. 
attest to a living tradition of science fiction in the twentieth century that shows no sign of letting go of the Verne paraphernalia. ${ }^{15}$ The curious circularity among Defoe, Verne, and some of today's science fiction says something very interesting about the historical status of the earlier text as an anticipation, a form-giving moment calling for its actualization in repeated imitations by future writers. Pierre Macherey has made a brilliant observation about the meaning of this circularity in an essay on Jules Verne: "All those who have wanted to settle their accounts with Robinson Crusoe-Jules Verne amongst others-have achieved this in so far as it allowed them to criticise a certain representation of origins. This critique depends on revealing the circularity of origins." ${ }^{16}$ For Verne, each rewriting of Crusoe constitutes a new statement about science fiction and its reworking of the terms of reality. "To outline a new Crusoe, intended as a symbol of reality, is to pose the problem of fiction and its reality, and consequently the problem of its mistaken irreality: all these problems in a single necessary moment." ${ }^{17}$

My point is not to introduce a deliberate rupture between Robinson Crusoe and Watt's realist tradition in order to reclassify Defoe's work as science fiction, although that certainly is a genuine possibility. For the purpose of this essay, I am more interested in pursuing what there is about Defoe's novel to which Rousseau, Verne, and many others have responded so spontaneously and powerfully through the centuries, in spite of its worn motif of maritime adventure. This analysis in turn may help us rethink the realism of Robinson Crusoe as a process of becoming, whereby one must learn to overlook the traces of science fiction $a$ priori in order to imagine the work as a realist novel. This learning process finds its own historical roots in the poetics of colonial disavowal mentioned aboveshared by Defoe and the majority of his critics-that almost always grounds the realism of this novel in the purported absence of the other and, therefore, at the expense of the other.

Let me be more specific. The science fiction of Defoe's time, like that of our own, was closely linked to what was going on in the actual laboratory. In regard to true porcelain, serious laboratory experiments were undertaken by Ehrenfried Walter von Tschirnhaus and the alchemist Johann Friedrich Böttger in Saxony at the turn of the century, leading to the founding of the Meissen factory in 1710 . We know that between 1712 and 1722 the Jesuit missionary Père d'Entrecolles (whose Chinese name is Yin Hongxu) conducted his famous industrial espionage on the Chinese porcelain metropolis Jingdezhen (King-te-Tching) and sent back two long letters from China. These letters were subsequently excerpted extensively

15. I thank Caren Kaplan and Eric Smoodin for mentioning these films to me.

16. Pierre Macherey, A Theory of Literary Production, trans. Geoffrey Wall (London, 1978), pp. 241-42. Incidentally, the quote might be useful in helping us think about J. M. Coetzee's novel Foe (New York, 1987).

17. Ibid., p. 233. 
by Jean-Baptiste Du Halde in his book Description géographique, historique, chronologique, politique, et physique de l'empire de la Chine (1735) and became popular across Europe as a result. (My speculation: Defoe could have read or heard about d'Entrecolles's first letter of 1 September 1712, which was published as early as 1716 in the Journal des Savants.) D'Entrecolles's report on the preparation of the essential components of porcelain, kaolin and petuntse, aroused widespread scientific interest among European scientists. ${ }^{18}$ The French physicist René Antoine Ferchault de Réaumur subsequently used the information d'Entrecolles gathered to carry out his much publicized research on the Chinese stone as he attempted to transmute glass into true porcelain. Britain was very much part of this process in the development of its own scientific and aesthetic apparatus. ${ }^{19}$ When Defoe published the first two volumes of Robinson Crusoe in 1719, Britain had not yet discovered the secret of white porcelain and relied on trade and its growing maritime power to meet the domestic demand for imported Chinese and Japanese trade porcelain and then Meissen products. Not until after the middle of the eighteenth century did Britain begin to acquire large-scale manufacturing capabilities, first in soft-paste porcelain and then in true porcelain.

Defoe's manufacture of bricks and pantiles was in every sense a part of this larger story. However, a biographical reading of Robinson Crusoe would not satisfy us as a way of anchoring its ceramic realism because the novel also participated in a larger, collective enterprise that enabled the scientists and novelists to fantasize collectively about a goal and an object in the manner of science fiction. Regardless of how successful Defoe was with his pantiles in real life manufacture, what Robinson Crusoe does so well in the novel is mimic the experiments of Tschirnhaus, Böttger, Réaumur, and Dutch potters who dreamed of being the first to replicate porcelain, especially white porcelain. ${ }^{20}$ Whereas the scientists unabashedly relied on industrial espionage or stolen specimens brought to Europe by sea merchants, Crusoe's solitary experiment requires no external help. Was porcelain not a type of earthenware that a British man could have invented all by himself?

Indeed, the author of Robinson Crusoe maneuvers the figural rivalry of earthenware and porcelain of his time so skillfully that one could easily overlook the traces of science fiction in the novel, as they have been consistently overlooked by his critics in the past and present. I argue that such maneuvering anticipated and contributed to a historical process in which the elements of science fiction seem to have fallen out of the pic-

18. Shortly before d'Entrecolles, Le Comte had also written about Chinese porcelain and its manufacture in 1697 .

19. See below for further discussion.

20. Defoe's pantiles were S-shaped, varnished, and then glazed and had a fine red color with good texture, which suggests a Dutch import. See Backscheider, Daniel Defoe, p. 64 . 
ture altogether so that a realist or spiritual reading would come to dominate the interpretation of the novel, often conceived sans volumes 2 and 3. The same process has coincided with a historical development whereby Europe's increasing mastery of the technologies of other civilizations produced the very ground on which the primitiveness and backwardness of those civilizations would be mythologized.

\section{What a Translated Text Can Tell Us That the Original Cannot}

Let us recall one or two important details in the earthenware episode of Robinson Crusoe. Crusoe's experiment with pottery making takes place after he has successfully learned the rudimentary techniques of agriculture on the island. He has spent two solitary years on the island and has begun to harvest the fruit of his labor, such as barley, corn, and rice. One day, realizing that he needs some containers for preparing corn and grains and so forth, he sets out to make earthen vessels. It takes him two months to find the clay, dig it, temper it, bring it home, and work it into reasonable shapes. In the course of doing this, he has to overcome numerous difficulties trying to raise the clay from the ground and to prevent its cracking under the violent heat of the sun. After repeated failures and frustrations, Crusoe succeeds in making two large, sun-baked earthenware vessels, as well as some little round pots, flat dishes, pitchers, and pipkins (small earthen pots) (fig. 1). Although Crusoe is not completely happy with the large pots and calls them "two large earthen ugly things," he finds them useful. He puts them in two big wicker baskets and stuffs the space between the pots and baskets with dry rice and barley straw, intending to use these to hold dry corn and grains. The problem is that his sun-baked vessels can neither hold water nor withstand fire. Crusoe being Crusoe, he never runs out of luck. Instead he makes a chance discovery of some sort of porcelain, or what some would have called chinaware:

It happen'd after some time, making a pretty large Fire for cooking my Meat, when I went to put it out after I had done with it, I found a broken Piece of one of my Earthen-ware Vessels in the Fire, burnt as hard as a Stone, and red as a Tile. I was agreeably surpris'd to see it, and said to my self, that certainly they might be made to burn whole if they would burn broken.

This set me to studying how to order my Fire, so as to make it burn me some Pots. I had no Notion of Kiln, such as the Potters burn in, or of glazing them with Lead, tho' I had some Lead to do it with; but I plac'd three large Pipkins, and two or three Pots in a Pile one upon another, and plac'd my Fire-wood all round it with a great Heap of Embers under them; I ply'd the Fire with fresh Fuel round the out-side, and upon the top, till I saw the Pots in the inside red 


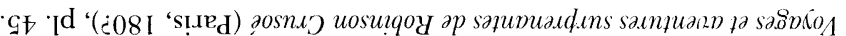

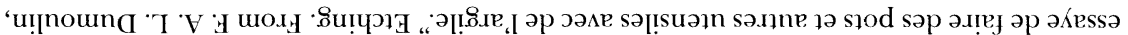

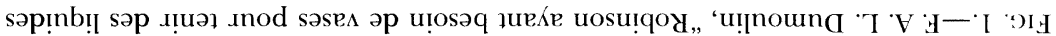

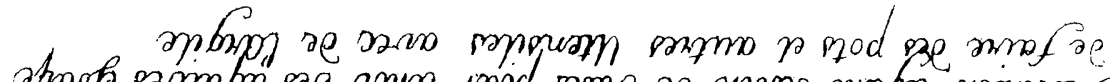

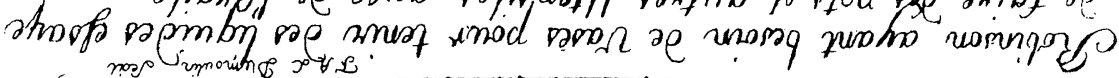

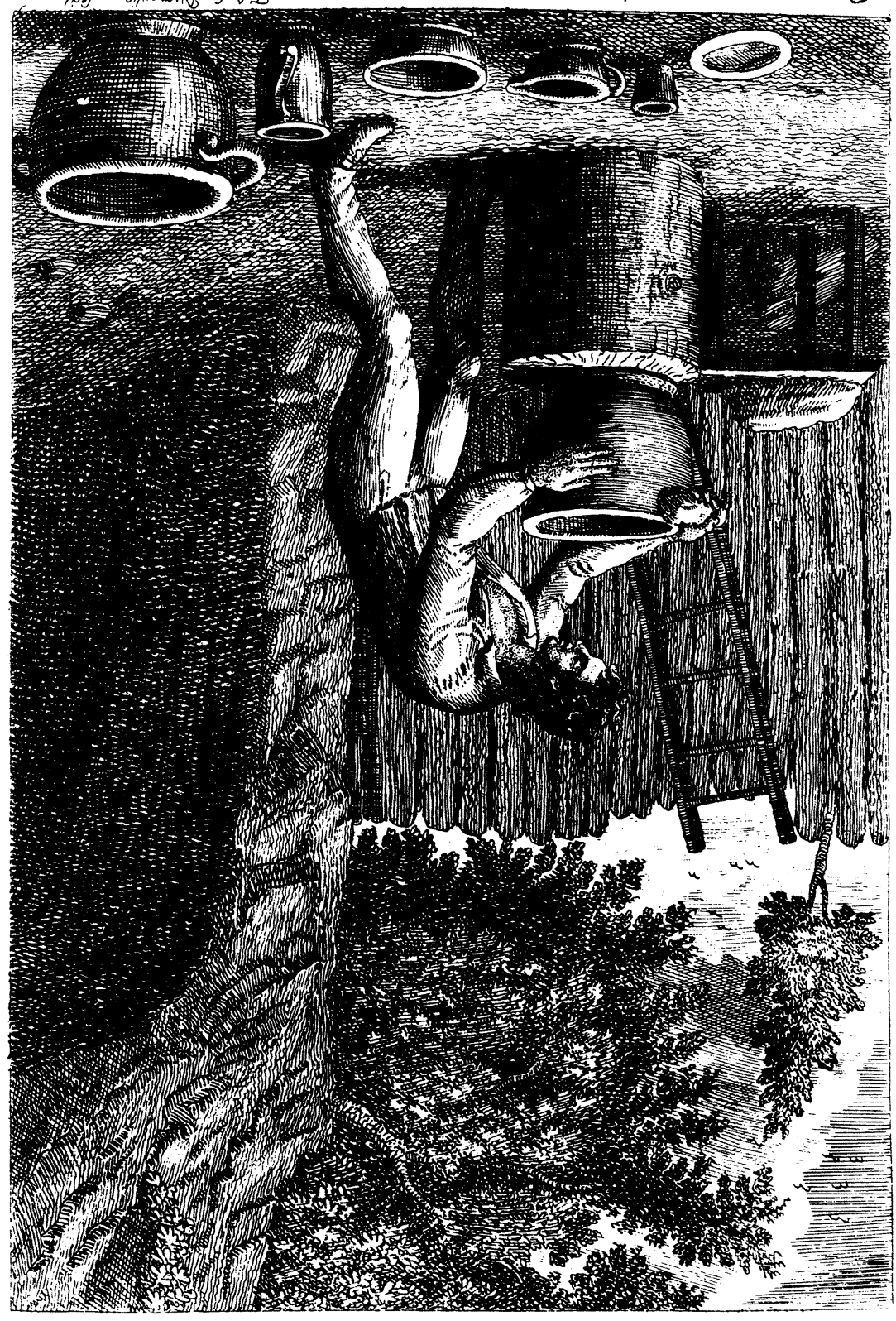


hot quite thro', and observ'd that they did not crack at all; when I saw them clear red, I let them stand in that Heat about 5 or 6 hours, till I found one of them, tho'd it did not crack, did melt or run, for the Sand which was mixed with the Clay melted by the violence of the Heat, and would have run into Glass if I had gone on; so I slack'd my Fire gradually till the Pots began to abate of the red Colour, and watching them all Night, that I might not let the Fire abate too fast, in the Morning I had three very good, I will not say handsome Pipkins; and two other Earthen Pots, as hard burnt as cou'd be desir'd; and one of them perfectly glaz'd with the Running of the Sand..$^{21}$

Crusoe's experiment has the innocent appearance of a chance discovery and, at first glance, does not stand out from the rest of his ingenious inventions at all. Nor does Crusoe make a verbal distinction between his sun-baked pottery and the new invention as he continues to call the perfectly glazed vessel an "Earthen Pot," as if the firing process made no qualitative difference whatsoever (fig. 2). ${ }^{22}$ Nevertheless, the similes I highlighted, "burnt as hard as a Stone, and red as a Tile," seem to gesture toward something without actually naming it. The figurative equivalence running through earthenware, stone, and tile invites us to see the earthenware in a different light. Suppose we allow the subjunctive element in the similes to play itself out a bit. Suppose Crusoe's similes behaved like a slip of the tongue. Would they suggest traces of a different order of meaning, which Defoe has banished perfunctorily from the narrative but which has, somehow, found its way back into the text through the similes? Indeed, why "hard as a Stone, and red as a Tile"?

The short answer is that Crusoe's earthenware pot simultaneously evokes and disavows the palpable presence of Chinese porcelain and all the associative meanings this image could call up in the minds of Defoe's contemporary European readers, like chinaware, delftware, faïence, maiolica, the porcelain towers that were being constructed in parks and gardens around Europe, chinoiserie, and so on. Now, a more interesting question is how we unravel the (con)textual implications of this simultaneous act of evocation and disavowal, and on what grounds. Before I elaborate on the similes themselves in the European context, I would like to bring a heretofore unknown text to the attention of Defoe scholars, namely, a foreign-language translation of Robinson Crusoe. This text is fascinating in the sense that it offers itself up as a belated metonymic reminder of the traces of porcelain making in the original novel by renaming the object as such. The work I have in mind is the first Chinese translation of Robinson Crusoe by the celebrated translator Lin Shu and his English-

21. Defoe, Robinson Crusoe, ed. Michael Shinagel, 2d ed. (New York, 1994), p. 88; emphasis added.

22. It is interesting that Crusoe mentions sand, because sand was among several materials, such as chalk, gypsum, alabaster, and ferruginous stone, upon which eighteenthcentury scientists experimented to approximate the translucent texture of true porcelain. 


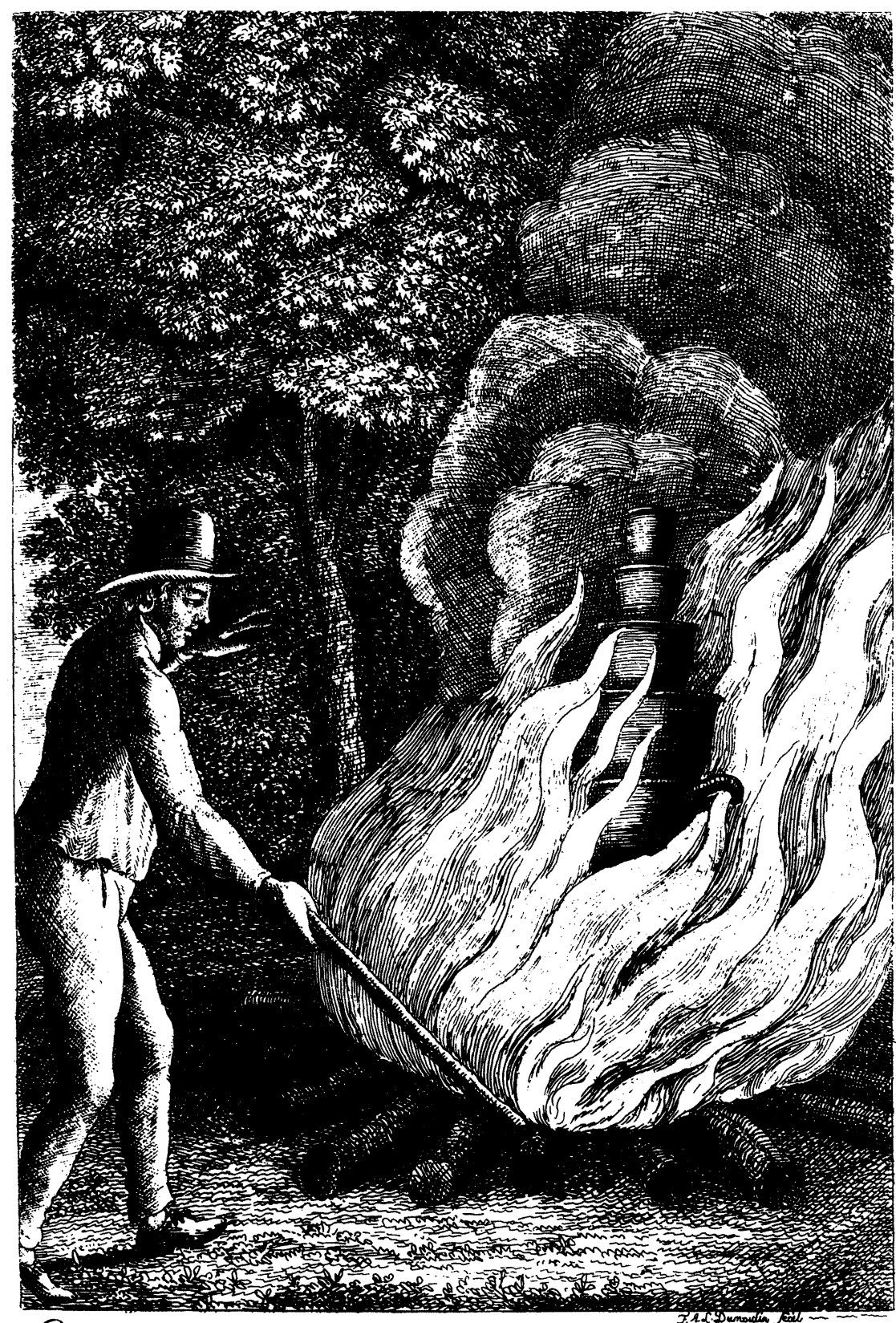
Robenson aprés plusicurs "efsays infuectucuxx reufsit á cuire ses vases de terre en les envivonanant de feuse bien ardents.

FIG. 2.-F. A. L. Dumoulin, "Robinson après plusieurs essays infructueux réussit à cuire ses vases de terre en les environnant de feux bien ardents." Etching. From F. A. L. Dumoulin, Voyages et aventures surprenantes de Robinson Crusoé (Paris, 180?), pl. 46. 
language informant Zeng Zonggong, who published the first two volumes of the novel in classical Chinese in $1905-6 .{ }^{23}$ Lin and Zeng's work introduces what I call a metonymic encounter between Defoe's novel and its Chinese translation. The surprise encounter has the effect of estranging the reader, à la Shklovsky, from an otherwise thoroughly familiar English text. ${ }^{24}$

Let us consider the translated scene of Crusoe's experiment with clay and firing. In the Chinese version, Lin and Zeng took the liberty of correcting the novel's fuzzy terminology, not suspecting that Crusoe's work could well have been a piece of science fiction in Defoe's time. Where the author uses words such as "Earthen Ware," 25 "Earthen Pots," "Earthenware vessels," and so forth indiscriminately to designate the products of Crusoe's labor, Lin and Zeng decided to alter them to better reflect what seems to them the technological progress Crusoe makes from an elementary form of pottery, $w a$, to porcelain, $c i$ or $t a o .{ }^{26}$ (Incidentally, the one place where Defoe does speak of china and porcelain is in his description of Crusoe's travels in China in the second volume of the novel. I will tackle this episode later on.) The Chinese translators' decision to improve the original text opens up an interesting interpretive space in which the historicity of the original stands exposed and is held accountable to the translated text.

This seems to reverse the usual relationship between the original text and its translation, as the burden of translatability shifts the plenitude of meaning onto the act of translation or interpretation. In that sense, I find

23. Lin Shu rendered and published the first two volumes of Robinson Crusoe in 1905-6. This happened at a time when the various English editions of Robinson Crusoe being published were omitting the second and third volumes. Volume 2 is The Farther Adventures of Robinson Crusoe, Being the Second and Last Part of His Life, and of the Strange, Surprizing Accounts of His Travels Round Three Parts of the Globe in which Crusoe makes a trip to the East Indies and recounts his adventures in South Asia, China, and Russia. See below for my discussion of Crusoe's alleged encounter with a porcelain house in China.

24. From a personal point of view, this has been one of the most rewarding translingual encounters I have come across. For a discussion of the epistemological implications of the recent encounter between Chinese, English, and other languages, see my book Translingual Practice: Literature, National Culture, and Translated Modermity-China, 1900-1937 (Stanford, Calif., 1995), pp. xv-42.

25. Defoe, Robinson Crusoe, p. 89.

26. While the distinction between $w a$ on the one hand and $t a 0$ and $c i$ on the other is clear, Lin Shu uses the words $c i$ and $t a o$ interchangeably, as was often the case in early Chinese documents on porcelain. See Jiang Qi, Taoji (Records of pottery and porcelain) (ca. 1322-1325), Zhu Yan, Taoshuo (Description of pottery and porcelain) (1774), and Lan Pu, Jingdezhen taolu (History of pottery and porcelain in Jingdezhen) (1815). Modern Chinese scholars tend to make a sharper distinction between tao and $c i$. Fu Zhenlun, for example, renders Jiang Qi's tao (porcelain of Jingdezhen) as $c i$ in his translation of Jiang's classical text into modern Chinese. See his Zhongguo gu taoci luncong (Essays in ancient Chinese pottery and porcelain) (Beijing, 1994), p. 178. See also Fu's Mingdai ciqi gongyi (The art of porcelain making in the Ming dynasty) (Beijing, 1955), and Xiong Liao, Zhongguo taoci meishu shi (History of the art of pottery and porcelain in China) (Beijing, 1993). 
Walter Benjamin's evocation of what seems to be a ceramic object in "The Task of the Translator" extraordinary, if not utterly surreal:

Fragments of a vessel which are to be glued together must match one another in the smallest details, although they need not be like one another. In the same way a translation, instead of resembling the meaning of the original, must lovingly and in detail incorporate the original's mode of signification, thus making both the original and the translation recognizable as fragments of a greater language, just as fragments are part of a vessel. For this very reason translation must in large measure refrain from wanting to communicate something, from rendering the sense, and in this the original is important to it only insofar as it has already relieved the translator and his translation of the effort of assembling and expressing what is to be conveyed. ${ }^{27}$

Although Gefäß (vessel) need not refer to a ceramic object, the word Scherben (shards or fragments) strongly suggests that Benjamin probably did have that image in mind..$^{28}$ If the originality of his theory of translation turns on the figure of fragmented shards glued together to form a whole vessel, what are we supposed to make of the figure itself? ${ }^{29}$ Lin and Zeng's rendering of Crusoe's earthenware pot certainly does not resemble the meaning of the original, nor do they seem to incorporate the original's mode of signification in the manner of matching the shards of a vessel. Since the earthenware pot itself now becomes the object of interpretation, the problem of meaning Lin and Zeng's translation raises for us is of a

27. Walter Benjamin, "The Task of the Translator," Illuminations, trans. Harry Zohn, ed. Hannah Arendt (New York, 1969), p. 78.

28. See Benjamin, "Die Aufgabe des Übersetzers," Illuminationen: Ausgewählte Schriften, ed. Siegfried Unseld (Frankfurt am Main, 1961), p. 65. My speculation about Gefä $\beta$ is also supported by Benjamin's use of the image of Tonschale in a similar manner in his essay "Der Erzähler: Betrachtungen zum Werk Nikolai Lesskows." In it, Benjamin observes:

Die Erzählung, wie sie im Kreis des Handwerks-des bäuerlichen, des maritimen und dann des städtischen-lange gedeiht, ist selbst eine gleichsam handwerkliche Form der Mitteilung. Sie legt es nicht darauf an, das pure 'an sich' der Sache zu überliefern wie eine Information oder Rapport. Sie senkt die Sache in das Leben des Berichtenden ein, um sie wieder aus ihm hervorzuholen. So haftet an der Erzählung die Spur des Erzählenden wie die Spur der Töpferhand an der Tonschale ["The storytelling that thrives for a long time in the milieu of work-the rural, the maritime, and the urban-is itself an artisan form of communication, as it were. It does not aim to convey the pure essence of the thing, like information or a report. It sinks the thing into the life of the storyteller, in order to bring it out of him again. Thus traces of the storyteller cling to the story the way the handprints of the potter cling to the clay vessel."] [Benjamin, "Der Erzähler: Betrachtungen zum Werk Nikolai Lesskows," Illuminationen, p. 418; "The Storyteller: Reflections on the Works of Nikolai Leskov," Illuminations, pp. 91-92]

29. It is interesting that Derrida seizes on this image in his own elaboration on Benjamin's theory of translation. See Jacques Derrida, "Des Tours de Babel," trans. Joseph F. Graham, in Difference in Translation, ed. Graham (Ithaca, N. Y., 1985), pp. 165-207. 
different order and is, perhaps, more interesting than the challenge of the pure language ("reine Sprache") that Benjamin poses to translators and theorists in "The Task of the Translator." ${ }^{30}$ What I mean is that the literality of Benjamin's ceramic figure must be interrogated in the performativity of translation, above and beyond whatever analogous value it might still carry for translation.

As a central trope of translation, the figure of the vessel can, therefore, be tested by Lin and Zeng's peculiar rendering of Crusoe's earthenware from English to classical Chinese. Contrary to the enormous symbolic significance Woolf once attached to this humble object, Lin and Zeng stare Crusoe's earthenware pot in the face and try to pin down the literal signification of Crusoe's experiment in the classical Chinese terminology with which they were familiar. The solidity and earthiness of the pot thus turn out to be very different degrees of solidity and earthiness as we follow Crusoe making progress step by step from the sun-baked wa to a chance discovery of $c i$ or tao.

What Lin and Zeng did to Defoe's novel seems to push the literal meaning of Crusoe's earthenware pot to the limit by referring it elsewhere. They took Defoe's choice of words and transformed it into an itinerant sign in search of its classical Chinese equivalent that had been established through centuries of commercial usage. The words $c i$ and tao are, therefore, chosen as the closest equivalent to what Crusoe claims to have discovered, which suggests that the translators are retranslating something back to what has always already been translated as "porcelain" and "chinaware" by Europeans in the past but what has been overshadowed by Defoe's celebration of a British man's ingenuity in the novel. D'Entrecolles, for instance, glossed porcelaine specifically as tseki, a French romanization of the characters $c i$ and $q i$ (literally, "porcelain vessel") of the time. In the first letter about Jingdezhen he sent back to Europe in 1712, d'Entrecolles wrote: "La porcelaine s'appelle communément à la Chine tseki." 31 Although unaware of the discursive history of porcelain making between China and Europe that nonetheless preconditioned their own efforts as translators, Lin and Zeng's work effectively interrogates the literality of Defoe's similes and turns them inside out in the Chinese text.

In the Chinese version of the earthenware episode, the similes of stone and tile disappear and are replaced by the word $c i$ as the translators rename some of Crusoe's "Earthen Pots" while preserving wa and waqi for his sun-baked pottery. ${ }^{32}$ Where Crusoe says "I found a broken Piece

30. Benjamin, "Die Aufgabe des Übersetzers," p. 80.

31. Père d'Entrecolles, letter to Père Orry, 1 Sept. 1712, Lettres édifiantes et curieuses, écrites des missions étrangères, ed. Charles Le Gobien et al., 28 vols. in 26 (Paris, 1707-58), 12:272.

32. Crusoe's repeated use of the word earthenware appeared confusing to Lin and his English-language informant Zeng. They managed to replace most instances of this word with $c i$ and tao except in one case where they could not decide whether Crusoe makes 
of one of my Earthen-ware Vessels in the Fire, burnt as hard as a Stone, and red as a Tile," the classical Chinese text reads (when retranslated into English): "In the ashes I found a broken piece of the clay that, having been fired so long, had turned into a porcelain tile [ciwa]." ${ }^{33}$ By renaming the object "porcelain," the Chinese text renders entirely visible the direct material ties that had existed between China and Europe since the sixteenth century. That is to say, Crusoe's improved "pottery" is no more plain earthenware than Tschirnhaus's, Böttger's, and other Europeans' experimental replicas of Chinese porcelain. On the contrary, these belonged to an era when Europe was modernizing itself in the arts, science, technology, and material culture and did so by colonizing, appropriating, and (epistemologically) primitivizing the other civilizations. ${ }^{34}$

In the early eighteenth century, Chinese $c i$ or tao was a desired equivalent of the European "porcelain" or "chinaware." Imitations of Chinese Yixing ware, known as red stoneware in Europe, and white porcelain may be said to represent a material act of translation aimed at overcoming any inaccuracies or nonequivalences of the sign with respect to the material it designated ${ }^{35}$ Their goal was to be able to reproduce the exact and equivalent value of true porcelain in terms of what was then called Porzellan or chinaware, which explains why the distinction between porcelain, faïence, and earthenware became of paramount importance. ${ }^{36}$ Curiously,

porcelain or a mixture of porcelain and inferior pottery. Hence, the word wayu (sun-baked vessel) is used once along with $c i$. The word $w a$ is used both as an adjective and as a noun, with a difference in meaning. As an adjective, it means "earthenware," as in wayu (earthenware vessel) and wapen (earthenware pot); as a noun, it means "tile," as in liuli wa (glass tile), ciwa (porcelain tile), and so forth.

33. Da Fu (Defoe), Lu Bingsun piaoliuji (Robinson's adventures), trans. Lin Shu and Zeng Zonggong, 2 vols. (Shanghai, 1905), 1:106. The word ciwa is glossed as "porcelain tile," but it could also reflect Lin and Zeng's indecision over $c i$ and $w a$ as used in Defoe's text.

34 . The rise of the rococo style was greatly indebted to chinoiserie and was grasped by contemporaries as distinctly modern. It arose because of the expansion of global trade and the emergence of a new market in Europe whereby the artist-artisan producers of rococo work (cabinetmakers, jewelers, engravers) were to some extent producing for themselves and each other. Patricia Crown points out that "'modern' was an exact synonym for Rococo" (Patricia Crown, "British Rococo as Social and Political Style," Eighteenth-Century Studies 23 [Spring 1990]: 274).

35. Yixing ware was named after the town Yixing in the province of Jiangsu where such red-tinted ware was produced. This ware became fashionable in China in the sixteenth and seventeenth centuries and was widely collected by the literati. See Fu, Zhongguo gu taoci luncong and Mingdai ciqi gongyi. For a technical analysis of traditional Yixing ware in English, see Sun Jing, Ruan Meiling, and Gu Zujun, "Microstructure of Ancient Yixing Zisha Ware Excavated from Yangjiao Hill," in Scientific and Technological Insights on Ancient Chinese Pottery and Porcelain: Proceedings of the International Conference on Ancient Chinese Pottery and Porcelain Held in Shanghai from November 1 to 5, 1982, ed. Shanghai Institute of Ceramics, Academia Sinica (Beijing, 1986), pp. 86-90.

36. In the literature of the period, as in Gay's poem mentioned in note 8, the difference between chinaware (porcelain) and earthenware was constantly exploited as a metaphor. 
Defoe's intervention consisted in severing that equivalence and decontextualizing the transcultural meanings of Crusoe's labor to turn it into myth. However, the myth is not complete and has left some traces behind because, as I have suggested, Crusoe's mimicking of the contemporary experiment inadvertently articulates his own condition of science fiction.

Being a business entrepreneur himself in brick and pantile manufacture, Defoe knew enough of the subject to describe Crusoe's experiment in the common parlance of his time, that is, as stone or tile. His description of the color of the object instantly reminds us of the red stoneware (Jaspisporzellan) and red Dutch floor tiles that John and David Elers made in England and Tschirnhaus and Böttger were producing after 1708 at the factory in Dresden-Neustadt, both trying to imitate Chinese Yixing ware through the example of Dutch potters. ${ }^{37}$ But I am not trying to get at a realistic or referential reading of Defoe's novel, nor do I wish to take the posed naivete of the narrator literally. There is no reason why Crusoe's fictional naiveté should be an alibi for us not to explore what alternative reading of Defoe's novel could perhaps emerge from the set of circumstances I am putting together. I argue, rather, that Defoe's use of the similes of stone and tile is more substantial than a mere rhetorical turn of language. Like the Chinese translation I discussed above, the similes gesture toward what has been disavowed in the novel.

The disavowal is singularly striking when we consider further how Defoe discusses Chinese porcelain in some other venues. In an account of Queen Mary's passion for chinaware in From London to Land's End, for example, Defoe exhibits up-to-date knowledge of the differences between chinaware and soft-paste porcelain. He writes:

Her Majesty had here a fine apartment, with a set of lodgings for her private retreat only, but most exquisitely furnished, particularly a fine chintz bed, then a great curiosity; another of her own work while in Holland, very magnificent, and several others; and here was also her Majesty's fine collection of Delft ware, which indeed was very large and fine; and here was also a vast stock of fine china ware, the like whereof was not then to be seen in England; the long gallery, as above, was filled with this china, and every other place where it could be placed with advantage. ${ }^{38}$

Delftware is a type of soft-paste European porcelain, and the term is often used interchangeably with faïence due to the regional differences of European porcelain manufacture in the early eighteenth century. George Sav-

37. For a study of English earthenware and its Dutch and Chinese connections, see A. H. Church, English Earthenware: A Handbook to the Wares Made in England during the Seventeenth and Eighteenth Centuries as Illustrated by Specimens in the National Collections (1884; London, 1904).

38. Defoe, From London to Land's End (London, 1892), p. 18; emphasis added. 
age restricts the proper use of faience to "pottery having a glaze made opaque with tin oxide when it has been made in Germany or France. The same kind of pottery made in Italy is termed maiolica, and in Holland and England, delft. The geographical line of demarcation is a little difficult to draw rigidly. It would, in fact, be better to regard the definitions of maiolica and delft as fixed, and to refer to tin-glazed pottery made elsewhere as faience." ${ }^{39}$ Whether or not we accept Savage's definition of early European soft-paste imitations of Chinese porcelain, this category was in the process of being conceptually differentiated from earthenware on the one hand and imported chinaware on the other. Could we surmise that Defoe's knowledge of the ceramics, not the lack of such knowledge, was the likely source of his disavowal?

The question draws our attention to a possible process of substitution in the figuring of Crusoe's earthenware pot, which one might call a metaphorical endeavor. Defoe's substitution of earthenware for porcelain seems to contradict the metonymic impulse of the similes, which unwittingly evoke that which is being disavowed. The conflicting coexistence of the metaphorical and the metonymic in the figuring of the earthenware pot is what enables the simultaneous disavowal and evocation of porcelain in Robinson Crusoe. As readers may recall, Woolf sees a plain "earthenware" pot in the foreground and tries to wrestle symbolic meanings from it, but she does so without taking Defoe's metaphorical disavowal of porcelain into consideration. In the very act of questioning the self-made British hero, her reading has the effect of reproducing the mirage of a self-sufficient British man who lords it over the rest of world as if it were, indeed, "a background of broken mountains and tumbling oceans with stars flaming in the sky," strangely devoid of civilizational resources and passively submitting to the manipulation of the white man's technology. But has Britain or Europe been self-sufficient and selfexplanatory in the arts, science, and technology? Of course not. As my reading of the earthenware episode has demonstrated, the idea of selfsufficiency is itself the ideological effect of a storytelling (and a Defoe industry) that aims to produce its own realism by selectively disavowing the elements of science fiction as a condition of the novel's realism.

At the heart of it all lies the poetics of colonial disavowal. The earthenware episode is by no means an isolated example. Hulme, for example, mentions two other such instances of disavowal, both having to do with Crusoe's pedagogical efforts to civilize Friday, the cannibal. The key episodes in Friday's education center on the two aspects of Carib technology, the barbecue and the canoe, that Europe learned from the Caribbean. In the novel, however, Crusoe teaches Friday how to barbecue and how to build a canoe, remarking that Friday is filled with gratitude and admiration for his technology. "The 'ignorance' of the savage Caribs is produced 
by the text of Robinson Crusoe," observes Hulme, "which enacts a denial of those very aspects of Carib culture from which Europe had learned" ( $C E$, pp. 210-11).

\section{The Metaphysical Turn of True Porcelain}

The concept of true porcelain was a European coinage with no corresponding term or category in native Chinese discourse on porcelain. ${ }^{40}$ Eighteenth-century European potters and scientists had invented this concept to distinguish between Chinese porcelain and its European counterpart. The introduction of true porcelain thus instituted a metaphysical divide between real porcelain and that which merely looked real. In this scheme of things, true porcelain specifically referred to Chinese porcelain whereas European faïence was relegated to the category of the superficial, waiting to be improved. This seems to be mapping true porcelain onto the metaphysics of eighteenth-century science where truth was supposed to reside inside, always underneath the surface. But how does one go about unmasking the truth of porcelain without breaking it? What would be the potential scientific and economic return of such unmasking?

The painstaking quest for the right clay-kaolin-and the right stone-petuntse-in the eighteenth century is illuminating because it brings our discussion of the metaphysics of true porcelain to the scientific realm of value and truth. From the time when Europeans believed that true porcelain was made by burying an earthenware piece in the ground for a long time to their discovery of local variants of kaolin and petuntse, there had been a fascinating history of cross-cultural value-making that had everything to do with the assumed or contested translatability of the sign, knowledge, and epistemology between China and Europe.

European writers and experimentalists had long been interested in the mystery of the precious translucent material of Chinese porcelain and, with the exception of a few isolated experiments, their speculations had hardly reached beyond Marco Polo's early account. Take the following passage from a 1617 publication: "A large mass of material composed of plaster, egg- and oyster-shell, of sea-locusts and similar creatures, is well mixed until it is of one consistency. It is then buried by the head of the family, who reveals the hiding place to only one of his sons. It must remain in the ground for eighty years without seeing the light of day. After this time has elapsed, the heirs must take it from the ground, and use it to make the beautiful translucent vases of such perfect form and colour that no critic could find fault with them." ${ }^{41}$ Variants of the same myth

40. In the Tang dynasty, porcelain was described as "fake/simulated jade" (Fu, Zhongguo gu taoci luncong, p. 182).

41. Quoted in Michel Beurdeley, Chinese Trade Porcelain, trans. Diana Imber (Rutland, Vt., 1962), p. 10. 
survived through the seventeenth and early eighteenth centuries and found their way into the works of such writers as Sir Thomas Browne, Francis Quarles, William Cartwright, Richard Knolles, Thomas Shadwell, Sir Francis Bacon, John Donne, and Alexander Pope. William Forbes has pointed out that "Bacon writes in Sylva Sylvarum (1627) of 'Porcellane, which is an Artificiall Cement buried in the Earth a long time' and in New Atlantis (1627) of 'several Earths, where we put divers Cements, as the Chineses, do their Porcellane," and that Donne includes these lines in his "Elegie on the Lady Marckham": "'As men of China, "after an ages stay, / Do take up Porcelane, where they buried Clay."” Forbes further notes that "China's Earth" is evoked precisely in this meaning by Pope in his poem The Rape of the Lock. ${ }^{42}$

Defoe did not succumb to the old myth and knew what he was talking about when he made his fictional hero discourse on the clay, kiln, glaze, lead, firing, sand, glass, stone, tile, and so on. Having owned a brick factory himself, Defoe's knowledge of contemporary experiments with porcelain, faïence, and delftware was sufficiently up to date. Prior to his Essex factory, several attempts had been made to reproduce the Dutch version of Chinese Yixing ware using the local clay found in England. Francis Place (1647-1728) undertook experiments with grey stoneware in his workshop at Manor House, York. His work was followed by that of John Dwight (1637-1703), who started a pottery in Fulham and was granted a patent to make porcelain in 1671. According to one account, Dwight brought a lawsuit against the Elers brothers for infringement of his patent. The Elers arrived from Holland some time before 1686, working in Hammersmith at first and later starting a factory in Staffordshire. They made red, unglazed stoneware in the manner of Chinese Yixing ware. The lawsuit showed that the ware produced by Dwight and by the Elers was identical. ${ }^{43}$ The Dutch connection in Defoe's manufactory was also strong. ${ }^{44}$ According to Backscheider, Defoe's knowledge of pantiles and of civet suggests that "he may have gone to Holland for a short business trip at least, but the numbers of Dissenters educated there and of

42. William Forbes, "The Rape of the Lock: An Unnoticed Significance of 'China's Earth," Notes and Queries, n.s. 34 (Sept. 1987): 342.

43. See Church, English Earthenware, pp. 44-55. For detailed information on the early experiments of John Dwight and the Elers brothers, see Eliza Meteyard, The Life of Josiah Wedgwood, from His Private Correspondence and Family Papers in the Possession of Joseph Mayer, Esq., F.S.A., F. Wedgwood, Esq., C. Darwin, Esq., M. A., F.R.S., Miss Wedgwood, and Other Original Sources, 2 vols. (London, 1865-66).

44. For a detailed archival study of the historical interactions among Dutch and Chinese traders and manufacturers, see T. Volker, Porcelain and the Dutch East India Company: As Recorded in the "Dagh-Registers" of Batavia Castle, Those of Hirado and Deshima, and Other Contemporary Papers, 1602-1682 (Leiden, 1954). For related studies, see Carolyn Saville Woodward, Oriental Ceramics at the Cape of Good Hope, 1652-1795: An Account of the Porcelain Trade of the Dutch East India Company with Particular Reference to Ceramics with the V.O.C. Monogram, the Cape Market, and South African Collections (Cape Town, 1974). 
English merchants who regularly visited the continent confuse the issue. Even had he been in Holland, Defoe probably would have had to hire a Dutch foreman or overseer." As late as 1726, Defoe's trade in pantiles made him a pioneer in manufacturing what was still called "a late Invention in England." 45

While this was going on, Tschirnhaus and Böttger were developing their own red stoneware with the help of a Dutch potter in DresdenNeustadt (before the formal establishment of the Royal Saxon Porcelain Manufactory in Meissen on 23 January 1710). Their goal, however, was to replicate white porcelain. ${ }^{46}$ Both men were Defoe's contemporaries and were in the service of Augustus II (Augustus the Strong), Elector of Saxony and King of Poland (1670-1733), whose passion for Chinese porcelain is legendary. Augustus is said to have exchanged a regiment of dragoons for forty-eight Chinese vases. In his lifetime, he owned thousands of pieces of porcelain, sponsored the Meissen factory, and intended to fill the Holländische Palais in Dresden-Neustadt with porcelain; this building, which he renamed the Japanische Palais in 1717, might have provided a real-life model for Defoe's porcelain house in The Farther Adventures of Robinson Crusoe, the second volume of Robinson Crusoe. ${ }^{47}$ In light of our analysis of the earlier earthenware episode, the inclusion of a porcelain house in the sequel that Defoe published in 1719 should shed some interesting light on the novel as a whole.

In The Farther Adventures of Robinson Crusoe, the aging Crusoe decides to undertake a final adventure abroad. After a sentimental journey to his former island, which is now governed by himself and colonized with human subjects and animals, Crusoe journeys on to the East Indies to explore the northern route to Western Europe. After surviving numerous life-threatening situations, he arrives in China in the company of some Jesuit missionaries and merchants. One day, his old Portuguese pilot comes upon a porcelain house and urges him to see this marvelous thing, which he thinks is a "gentleman's house built all with China Ware." Defoe writes:

Well, said I, are not the Materials of their Building the Product of their own Country; and so it is all China Ware, is not it? No, no, said he, I mean it is a House all made of China Ware, such as you call it in England; or as it is call'd in our Country, Porcellain. Well, said I, such a thing may be; how big is it? Can we carry it in a Box upon a Camel? If we can, we will buy it. Upon a Camel! said the old Pilot,

45. Backscheider, Daniel Defoe, pp. 64, 65.

46. See Jan Diviš, European Porcelain, trans. Iris Urwin (New York, 1983), pp. 26-27, and Savage, Eighteenth-Century German Porcelain, pp. 28, 52-56.

47. Volume 2, The Farther Adventures of Robinson Crusoe, was published by William Taylor on 20 August 1719, and volume 3, entitled Serious Reflections during the Life and Surprising Adventures of Robinson Crusoe: With His Vision of the Angelick World, appeared on 6 August 1720. 
holding up both his Hands, why there is a Family of thirty People lives in it.

I was then curious indeed to see it, and when I came to it, it was Nothing but this: it was a Timber-House, or a House built, as we call it in England, with Lath and Plaister, but all the Plaistering was really China Ware, that is to say, it was plaistered with the Earth that makes China Ware.

The outside, which the Sun shone hot upon, was glazed, and look'd very well, perfect white, and painted with blue Figures, as the large China Ware in England is painted, and hard as if it had been burnt: As to the inside, all the Walls, instead of Wainscot, were lined up with harden'd and painted Tiles, like the little square Tiles we call Gally-Tiles in England, all made of the finest China, and the Figures exceeding fine indeed, with extraordinary Variety of Colours, mix'd with Gold, many Tiles making but one Figure, but join'd so artificially with Mortar, being made of the same Earth, that it was very hard to see where the Tiles met. ${ }^{48}$

This extraordinary scene of encounter and unmasking may be read as a master allegory of eighteenth-century metaphysics. The goal of Crusoe's unmasking is to show that the chinaware house is not really a chinaware house but a building "plaistered with the Earth that makes China Ware." Since appearances can be deceiving, the building turns out to be nothing more than an ordinary timber house, like those built with lath and plaster in England. The glazed surfaces look exquisite on the outside, as do the tiles on the walls of the house inside. But if one were to penetrate the tiled surfaces, one would not expect to find the same kind of materials. Crusoe's penetrating eye does not content itself with the mere appearance of things, so he works to uncover the inner truth hidden somewhere else. This metaphysical will to truth implies a necessary act of violence toward the object and reminds us of the trope of "cutting, and opening, and mangling, and piercing" that Jonathan Swift satirizes so well in $A$ Tale of $a$ Tub. ${ }^{49}$ Inasmuch as Crusoe's act of unmasking turns china into a synecdoche of China (a pun made easy by early modern typography), the violence is directed at both. ${ }^{50}$

48. Defoe, The Farther Adventures of Robinson Crusoe, Being the Second and Last Part of His Life, and of the Strange, Surprizing Accounts of His Travels Round Three Parts of the Globe, vol. 2 of The Life and Strange Surprizing Adventures of Robinson Crusoe, of York, Mariner: Who Lived Eight and Twenty Years, All Alone in an Un-Inhabited Island on the Coast of America, Near the Mouth of the Great River Oroonoque, Having Been Cast on Shore by Shipwreck, Wherein All the Men Perished but Himself. With an Account How He Was at Last As Strangely Deliver'd by Pyrates (London, 1719), pp. 310-11; emphasis added.

49. Jonathan Swift, "A Tale of a Tub," to Which Is Added "The Battle of the Books" and "The Mechanical Operation of the Spirit," 2d ed. (Oxford, 1958), p. 173.

50. Commenting on China's Great Wall in volume 2, Crusoe observes: "Do you think it would stand out an army of our country people, with a good train of artillery; or our engineers, with two companies of miners? Would they not batter it down in ten days, that 
Crusoe's unmasking of the lie of the chinaware house and China appeared so successful that a later edition of Robinson Crusoe (1815) attaches a footnote, with the hindsight of a hundred years, to gloss the inferior cultural value of porcelain. The footnote contains a lengthy disquisition-with often erroneous technical information-on porcelain making and porcelain's European manufacture and concludes by saying:

The art of pottery among the Chinese, is one of the most remarkable. But this is a very simple one, and in fact invented by some of the rudest people. They are understood to have an earth possessing certain peculiar virtues in regard to this manufacture; and Barrow informs us, that the merit of their porcelain is less owing to any ingenuity they display in the making of it, than to the prodigious care with which they select the very finest materials, and separate them from all impurities. A very remarkable proof of their want of ingenuity is, that they should have been in possession so long of an art so analogous to that of making glass, and yet should never have been able to invent that beautiful and useful manufacture. Their want of taste in the shapes and ornaments of their vessels, is now proverbial. ${ }^{51}$

This bit of editorial wisdom carries Crusoe's fictional punning on "China Ware" (porcelain and Chinese art) into the unmistakable realm of nineteenth-century ethnographic realism. Such realism supports Crusoe's unmasking with the supposedly factual proof provided by Sir John Barrow and other ethnographic travelers of the nineteenth century, contributing directly to the "objective" status of Robinson Crusoe as a realist novel. The lie of china in Defoe's text is now clearly spelled out as the lie of China. ${ }^{52}$

But has any such thing as a porcelain house or porcelain room existed in China? The answer is no. Where did Defoe get his idea? Did he make the whole thing up for the sake of exoticizing another place? Not entirely. The probable immediate prototype that comes to mind is the famed chinoiserie pagoda tower that Max Emmanuel constructed for the park at Nymphenburg on the outskirts of Munich in 1719. This tower was an imitation of the Petit Trianon de porcelaine in Versailles, the earliest chinoiserie garden casino, made at the order of Louis XIV in 1670-71

an army might enter in battalia, or blow it up into the air, foundation and all, that there should be no sign of it left?" (Defoe, The Farther Adventures of Robinson Crusoe, p. 182). Defoe was an uncanny prophet when he put these words into the mouth of his character. The Anglo-Chinese wars in the nineteenth century would bear him out in Britain's premeditated destruction of the very physical symbols, if not the Great Wall itself, that the British had believed were the pride of Chinese civilization: the Yuanming Yuan Imperial Gardens, temples, and palaces.

51. Defoe, Robinson Crusoe, the Naval Chronicle ed. (London, 1815), pp. 433-34.

52. The evocation of glass is interesting because it runs counter to what eighteenthcentury scientists, such the French physicist Réaumur, would say about the relatively inferior technology of glassmaking. 
and decorated "'in the manner of works coming from China." ${ }^{33}$ The coincidence of these dates is revealing: the same year the pagoda tower was constructed, Defoe was writing and publishing his second volume of Robinson Crusoe. Also, as I suggested above, the Holländische Palais in Dresden-Neustadt that Augustus the Strong acquired in 1717 and renamed the Japanische Palais could be another source of inspiration for Defoe's porcelain house.

In 1700, Augustus found himself in desperate straits for means to finance his Swedish war, so he seized the alchemist Böttger, using a military escort to bring him to Dresden, to help transmute lead into gold for him. By 1703 no lead had been transmuted and forty thousand thalers had been wasted on a fraudulent project. Augustus lost patience and placed Böttger under the supervision of Tschirnhaus, whose scientific investigation of the secret of true porcelain was well under way. ${ }^{54}$ Tschirnhaus had studied at the University of Leiden from 1668 to 1674 and remained in close contact with the Académie royale des sciences during his early experiments with true porcelain. Much of his work involved melting a variety of highly refractory substances by concentrating radiant heat upon them with a concave iron reflecting mirror. ${ }^{55}$ Tschirnhaus also paid several visits to fellow scientists in Italy and France who claimed that they had found the secret of true porcelain. As several scholars have pointed out, this man's preoccupation with ever higher temperatures and his research into the melting point of various refractory substances demonstrate that "he had more than a glimpse of the principles underlying the manufacture of Chinese porcelain." ${ }^{56}$

Using his burning-mirrors, Tschirnhaus experimented with the melting point of asbestos, of a calcium magnesium silicate, and of what appears to have been a kind of kaolin. Apparently no kilns had been designed in Europe that were capable of reaching the firing temperature of true porcelain at 1,450 degrees celsius. Even though Tschirnhaus did not discover the china clay himself, his early chemical research did move in a direction that James Hutton (1726-97) would follow several decades later in developing the Plutonian theory of the earth whereby the modern science of geology was founded. ${ }^{57}$ When Tschirnhaus was joined by Bött-

53. Phillips, China-Trade Porcelain, p. 47.

54. Detailed information is found in Savage's discussion of the birth of the Meissen factory in Eighteenth-Century German Porcelain, pp. 22-92.

55 . Refractory substances result from chemical changes in a mixture of feldspar, granite, and pegmatite. They are an essential element of true porcelain, called kaolin in China after the name of the hills near Jingdezhen. This material fires white and composes the body of the paste. The essential fusible element is supplied by petuntse, which fuses under heat into a kind of natural glass.

56. Ibid., p. 24.

57. See below for a discussion of porcelain-related chemical experiments conducted by Réaumur. For a recent study of Hutton and his theory of the earth, see Dennis R. Dean, James Hutton and the History of Geology (Ithaca, N.Y., 1992). For a fascinating study of romanti- 
ger he had made considerable progress with his mirrors for achieving the maximum heat possible, even though the discovery of kaolin is often attributed to the latter scientist. ${ }^{58}$ The two men together developed a secret formula that contained alabaster instead of feldspathic rock (thought to be petuntse) as the fusible material to fire with kaolin. The porcelain they manufactured with this formula at the Meissen factory did not, however, exhibit the same degree of whiteness, consistency, and translucency as that of Chinese porcelain. It was not until after 1720-that is, after the death of both men and one year after Defoe published his novel-that alabaster began to be replaced by a feldspathic rock from Sieberlehn (Sieberlehnstein) that greatly improved and whitened the body. ${ }^{59}$ In that sense, the Meissen factory became the first manufacturer of white porcelain in Europe.

The relationship between glass and white porcelain was a popular subject of speculation in this period, as was amply evidenced by Defoe's novel and the 1815 edition of Robinson Crusoe I quoted above, mainly because the renowned French physicist Réaumur took a scientific interest in it. Réaumur was seeking to replicate true porcelain by heating glass packed in refractory powder in saggars in an ordinary potter's kiln. After experimenting with many cements, he came to prefer a mixture of sand and gypsum. He observed that the change in the nature of the glass started at the surface (a fact supporting the alleged chemical change) and grew inward in the form of silklike fibers that were composed of extremely fine grains. The glass could be made entirely granular, like ordinary porcelain, under some heat treatments. Réaumur called his product "porcelain by transmutation, by revivification, or porcelain from glass." "Glass," said he, "has a polish, a lustre, that is never seen in the fracture of true porcelain. Porcelain is granular, and it is partly by its fine grain that the fracture of porcelain differs from that of terra cotta, and finally it is by the size and arrangement of the grains in them that the kinds of porcelain differ from each other and become closer or less close in nature to glass." ${ }^{60}$ The theory behind this experiment is that if metals can be returned to the metallic state after being converted to their calces or dissolved in glass, why should not the sand and stones that gave rise to glass be restorable? As Cyril Stanley Smith has pointed out, the essentially Cartesian corpuscular views that had guided Réaumur's work on steel and iron served equally for porcelain. He was the last scientist for well over a century to have a serious concern with the structure of materials on this level. Réaumur set out to make white porcelain whose appearance

cism and geology, see Noah Heringman, "Aesthetic Geology, Romantic Rocks, and the Material Objects of Poetry" (Ph.D. diss., Harvard University, 1998).

58. See Savage, Eighteenth-Century German Porcelain, p. 25.

59. See ibid., p. 36.

60. Quoted in Cyril Stanley Smith, "Porcelain and Plutonism," in Toward a History of Geology, ed. Cecil J. Schneer (Cambridge, Mass., 1969), pp. 324, 323. 
and inside would have the same degree of consistency throughout, yet the result was disappointing because, though the inside of his porcelain matched the whiteness of the best Chinese ware, the surface was dark and rough. ${ }^{61}$ This seems to be Réaumur's own unintentional mockery of Crusoe's metaphysical unmasking of porcelain in The Farther Adventures of Robinson Crusoe.

As I observed in the beginning of this essay, Defoe's poetics of colonial disavowal was motivated by the economic rivalries of his time. The same can be said of the eighteenth-century scientific research into porcelain, which likewise rode on the wings of global economic forces and was determined to bring about a success story in Europe. Defoe did not live to hear that story. In competition with Chinese export porcelain, Wedgwood and the British ceramic industry, which emerged in the mid eighteenth century, succeeded in causing the decline of the former on the global market. Fernand Braudel attributes this decline to the natural cycle of fashion in The Structures of Everyday Life. ${ }^{62} \mathrm{He}$ is partially accurate with regard to eighteenth-century chinoiserie and the Franco-German rococo, yet we must not forget that the majority of export porcelain was increasingly intended for daily use either at the dining table, for the toilet, or in the drawing room. ${ }^{33}$ The aggressive stance with which Wedgwood marketed its products around the world and even shipped them to China does not seem to substantiate Braudel's argument about fashion and its natural cycle. ${ }^{64}$ Moreover, the changing tax laws in Britain during this time also pitted the native industries favorably against the importation of foreign porcelain. As several studies have pointed out, the most important determinant of the favorable balance of trade in Britain during this time was the rise of the percentage of its exports from 8 percent to 20 percent, much of which was due to the existence of Britain's and Europe's colonial economy. ${ }^{65}$

In this vein, I'd like to conclude my essay by adding a brief note to the familiar etymology of china and the curious definition of this word given by the authoritative dictionary of the English language. According to the Oxford English Dictionary, china derives from a Persian term, chini, that moved through India and eventually made its way into seventeenth-

61. See ibid., p. 326.

62. See Braudel, The Structures of Everyday Life, p. 186.

63. For a detailed study of inventories and markets for such items beginning in the 1720s, see Beurdeley, Porcelain of the East India Companies, pp. 39-47.

64. For a recent study of the rise of Wedgwood, see Neil McKendrick, "Josiah Wedgwood and the Commercialization of the Potteries," in The Birth of a Consumer Society: The Commercialization of Eighteenth-Century England, ed. McKendrick, John Brewer, and J. H. Plumb (London, 1983), pp. 100-145.

65. See Backscheider, Daniel Defoe, p. 532. See also W. A. Speck, Stability and Strife: England, 1714-1760 (Cambridge, Mass., 1979), p. 126; George Rudé, Hanoverian London, 1714-1808 (Berkeley, 1971), pp. 20-24, 32-35; and T. S. Ashton, An Economic History of England: The Eighteenth Century (London, 1955), p. 151. 
century English. The circulation of this word follows the ancient trading routes and, along with the Portuguese-derived etymology of porcelain, the etymology of china embodies the dual trading histories of England and Portugal in the past centuries. The Oxford English Dictionary goes on to define china as "a species of earthenware of a fine semi-transparent texture, originally manufactured in China, and brought to Europe in the 16th c. by the Portuguese, who named it porcelain." ${ }^{66}$ Apparently the $O x$ ford English Dictionary definition has not benefited from the scientific wisdom of the past centuries that would say otherwise. For to define china as a species of earthenware is to ignore the history of the scientific experiments in Europe which have thoroughly transformed the meaning and referent of this English word since the sixteenth century. As I have argued in this essay, Crusoe's disavowal of china in the earthenware episode and his subsequent unmasking of the chinaware house can only be meaningful insofar as they are seen as part of that history. My reading of Robinson Crusoe has attempted to recapture a sense of that history by crossexamining Defoe's life and work through the reverse lens of a Chinese translation that was itself a product of cross-cultural writing. What fascinates me in this process of cross-reading is the revelation of the extraordinary foreignness of Defoe's text. That foreignness is perhaps the site on which the historicity of the familiar is encoded. Like an act of translation, the epistemological encounter with the foreign in the familiar can introduce a radical difference into our reading of an otherwise thoroughly known text and context.

Appendix: A Glossary of Chinese Characters

\begin{tabular}{|c|c|}
\hline ci & 瓷 \\
\hline Da Fu (Defoe) & 達眾 \\
\hline Jingdezhen (King-te-Tching) & 景德鎮 \\
\hline kaolin & 高领 \\
\hline Lin Shu & 林紟 \\
\hline petuntse & 白不子 \\
\hline tao & 陶 \\
\hline tseki & 瓷器 \\
\hline wa & 瓦 \\
\hline waqi & 瓦器 \\
\hline Yin Hongxu (d'Entrecolles) & 殷宏緒 \\
\hline Yixing & 宜興 \\
\hline Yuanming yuan & 圆明園 \\
\hline Zeng Zonggong & 曾宗舫 \\
\hline
\end{tabular}

66. Oxford English Dictionary, s.v. "china." 
http://www.jstor.org

\title{
LINKED CITATIONS \\ - Page 1 of 1 -
}

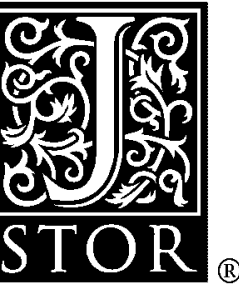

You have printed the following article:

\section{Robinson Crusoe's Earthenware Pot}

Lydia H. Liu

Critical Inquiry, Vol. 25, No. 4. (Summer, 1999), pp. 728-757.

Stable URL:

http://links.jstor.org/sici?sici=0093-1896\%28199922\%2925\%3A4\%3C728\%3ARCEP\%3E2.0.CO\%3B2-3

This article references the following linked citations. If you are trying to access articles from an off-campus location, you may be required to first logon via your library web site to access JSTOR. Please visit your library's website or contact a librarian to learn about options for remote access to JSTOR.

\section{[Footnotes]}

\author{
${ }^{34}$ British Rococo as Social and Political Style \\ Patricia Crown \\ Eighteenth-Century Studies, Vol. 23, No. 3. (Spring, 1990), pp. 269-282. \\ Stable URL: \\ http://links.jstor.org/sici?sici=0013-2586\%28199021\%2923\%3A3\%3C269\%3ABRASAP\%3E2.0.CO\%3B2-V
}

NOTE: The reference numbering from the original has been maintained in this citation list. 